\title{
Penelitian
}

\section{Deteksi Penyakit Bovine Viral Diarrhea pada Sapi Potong Impor melalui Pelabuhan Tanjung Priok}

\author{
(Detection and Risk Factors Study of Bovine Viral Diarrhea in Cattle Imports at Tanjung Priok Port)
}

\author{
Aditya Primawidyawan ${ }^{1,2^{*}}$, Agustin Indrawati , Denny Widaya Lukman ${ }^{3}$ \\ 'Balai Besar Karantina Pertanian (BBKP) Tanjung Priok, Badan Karantina Pertanian \\ ${ }^{2}$ Program Studi Kesehatan Masyarakat Veteriner Sekolah Pascasarjana Institut Pertanian Bogor, Bogor \\ 3Departemen IImu Penyakit Hewan dan Kesehatan Masyarakat Veteriner FKH IPB \\ *Penulis untuk korespondensi: widyawanaditya@gmail.com \\ Diterima 24 Mei 2015, Disetujui 23 September 2015
}

\begin{abstract}
ABSTRAK
Penelitian ini bertujuan untuk melakukan suatu kajian serologis tentang penyakit bovine viral diarrhea (BVD) dan mendeteksi adanya kaitan pemeliharaan kandang sebagai faktor risiko sumber penularan penyakit BVD pada sapi potong impor. Pengujian screening awal mengggunakan ELISA (enzyme linked immunosorbant assay) Antibodi BVD terhadap 100 sampel serum darah sapi, dan ditemukan 63 positif terhadap adanya antibodi anti BVD. Selanjutnya dilakukan pengujian lanjutan ELISA Antigen BVD dan hasilnya seluruh sampel negatif terhadap Antigen BVD. Hasil positif uji ELISA terhadap antibodi BVD mengindikasikan bahwa sampel mengandung antibodi anti BVD akibat pernah terinfeksi oleh virus BVD secara sementara (transient) atau melalui vaksinasi. Berdasarkan dokumen health certificate dari negara asal tidak terdapat informasi yang jelas terhadap perlakuan vaksinasi BVD pada sapi potong impor. Oleh karena itu diperlukan pemeriksaan screening di negara Indonesia untuk mendeteksi dan melakukan usaha preventif mencegah penyebaran di feedlot. Faktor-Faktor yang mempengaruhi kejadian hasil ELISA antibodi positif BVD, terkait dengan penyebaran penyakit BVD selama dalam masa pemeliharaan dan penggemukkan adalah program biosekuriti pada peternakan dengan nilai $(O R=3,316$; $\mathrm{Cl}=1,380-7,967)$, dan pengelolaan limbah kandang dalam peternakan dengan nilai $(\mathrm{OR}=2,667 ; \mathrm{Cl}=1,105-$ $6,434)$. Hasil ini menunjukkan ada asosiasi antara kedua faktor yang ada pada peternakan dengan kejadian penyakit BVD.
\end{abstract}

Kata kunci: BVD, ELISA antibodi dan antigen, faktor risiko

\begin{abstract}
This research was a serological study on bovine viral diarrhea (BVD) and also to detect the relevance of maintenance farm management as a risk factor on the spreads of BVD. The initial screening test was performed using antibody capture enzyme linked immunosorbent assay (ELISA) to BVD on 100 cattle blood serum samples. The screening test showed that of 63 samples were positive to BVD antibody and 37 samples were negative to BVD antibody. The next screening test was performed using antigen capture ELISA to BVD and all samples showed negative results on BVD antigen. The results of the ELISA test positive for antibodies to BVD indicates that the samples examined anti-BVD antibodies due to $B V D$ virus had been infected by a temporary (transient) or vaccination. Based on the document health certificate from the country of origin there is no clear information on the treatment of BVD vaccination on imports of beef cattle. So, we need a screening examination in the country of Indonesia to detect and perform preventive measures to prevent the spread in feedlots. Relevant factors that affected the occurrence of positive result on BVD antibody detection was farm biosecurity programs with odds ratio (OR) value of 3.316 and confidential interval $(\mathrm{Cl})$ value of 1.380-7.967. Further relevant factor was caging waste management with $\mathrm{OR}$ value of 2.667 and $\mathrm{Cl}$ value of 1.105-6.434. There were statistically significant differences $(p<0.05)$ between farm biosecurity programs and caging waste management related to BVD disease incidence.
\end{abstract}

Keywords: BVD, ELISA antibodies and antigen, risk factors 


\section{PENDAHULUAN}

Kebutuhan daging sapi dan kerbau Indonesia pada tahun 2012 untuk konsumsi sebanyak 484 ribu ton. Kebutuhan tersebut baru bisa dicukupi dari pemotongan sapi lokal sebanyak 399 ribu ton (82,5\%), sehingga masih terdapat kekurangan penyediaan sebesar 85 ribu ton (17,5\%). Salah satu cara untuk memenuhi kekurangan tersebut adalah dengan melakukan impor sapi potong dari Australia (DITJEN PKH 2012). Penelitian ini bertujuan untuk melakukan suatu kajian serologis tentang penyakit BVD serta mendeteksi adanya kaitan pemeliharaan kandang sebagai faktor risiko sumber penularan penyakit BVD pada sapi potong impor.

Penyakit bovine viral diarrhea (BVD) merupakan penyakit menular pada sapi yang disebabkan oleh virus. Virus ini mudah ditransmisikan diantara sapi dan telah menyebar luas ke seluruh dunia. Virus BVD dapat menular secara horizontal maupun secara vertikal (Middleton, 2006). Penyakit BVD telah bersifat endemik di Indonesia dengan tingkat prevalensi reaktor yang bervariasi dan di beberapa daerah cukup tinggi. Penyakit BVD di Indonesia pertama kali terjadi pada tahun 1988 dan menyerang sapi Bali, Brahman, Brahman Cross, Peranakan Ongole (PO) jantan maupun betina dari semua umur. Virus BVD memiliki morbiditas yang tinggi tetapi mortalitasnya sangat rendah. Pada tahun 2006 dilaporkan terjadi kasus BVD sebesar 1190 di Indonesia. Sudarisman (2011) menjelaskan bahwa dalam uji serologis ELISA terhadap serum serum sapi di berbagai daerah di Indonesia diketahui sebesar $37 \%$ sapi memiliki antibodi terhadap BVD. Secara horisontal dapat melalui sapi yang mengalami infeksi persisten sehingga menginfeksi sapi lain yang sehat. Secara vertikal, virus BVD dapat menular dari induk ke anaknya. Fetus yang tertular akan mengalami abortus dan pedet yang dilahirkan akan membawa virus secara persisten (Sudarisman, 2011). Dalam melaksanakan impor sapi potong, adanya penyakit pada ternak dapat menjadi ancaman. Salah satu ancaman penyakit hewan yang dapat menghambat pertumbuhan populasi dan produktivitas ternak sapi yaitu bovine viral diarrhea (BVD). Menurut office International des epizooties (OIE) BVD merupakan penyakit yang berpotensi membahayakan perdagangan internasional.

Kerugian ekonomi akibat penyakit BVD antara lain berupa gangguan reproduksi, hambatan pertumbuhan, menurunnya berat badan serta kematian. Pemerintah Indonesia harus memberikan perhatian khusus untuk mengatasi penyakit BVD ini demi ketahanan pangan dan terciptanya swasem- bada daging di negara Indonesia. Deteksi terhadap adanya hewan penular BVD (persistenly infection) sangat diperlukan sehingga diharapkan pencegahan yang efektif dalam penyebaran penyakit BVD pada sapi potong impor asal Australia di feedlot Instalasi Karantina Hewan BBKP Tanjung Priok. Penelitian ini diharapkan memberikan kontribusi dalam hal pencegahan penyakit BVD ini menyebar di feedlot.

\section{BAHAN DAN METODE}

\section{Bahan}

Bahan-bahan yang digunakan berupa kit ELISA BVD antibodi dan antigen (IDEXX), metanol (Merck no. 1.00983.2500), 20 mM tris-HCL (Merck no. 1.08382.0100), aquadestilata, tween 20 (Merck No. 8.22184.0500) serta $67 \mathrm{mM}$ fosfat buffer $\mathrm{pH}$ 7,2. Pengukuran hasil absorbansi spektrofotometer mengacu protokol K junior Bio-Tek. Pengukuran nilai absorbansi sampel pada $450 \mathrm{~nm}$.

\section{Metode Pengambilan Sampel}

Sampel yang diambil adalah serum darah sapi impor dari Australia yang masuk melalui Pelabuhan Tanjung Priok. Pengambilan sampel dilakukan secara acak sederhana hingga jumlah sampel terpenuhi. Setiap anggota populasi di dalam kerangka penarikan contoh diberi nomor $1,2,3, \ldots, \mathrm{N}$, kemudian contoh dipilih secara acak dari $\mathrm{N}$ anggota populasi tersebut. Pengacakan bisa menggunakan daftar bilangan teracak (DBT), kalkulator, ataupun komputer. Berdasarkan pertimbangan maka disepakati bahwa rancangan sampling yang digunakan adalah kajian lintas seksional. Prevalensi 57\% (hasil laporan serologis positif BVD tahun 2012 oleh BPPV Subang) dan galat $10 \%$, sehingga besaran contoh penelitian sebesar 100 sampel.

Kelompok faktor program biosekuriti dengan pengujian serum darah, kelompok peternakan dibagi menjadi kelompok biosekuriti buruk dan kelompok biosekuriti baik. Pengelompokan sampel yang diuji pada program biosekuriti berdasarkan penilaian pada pengawasan isolasi hewan yang baru datang, pengawasan terhadap lalu lintas manusia maupun peralatan dan kebersihan kandang di instalasi karantina hewan. Kelompok faktor pengolahan limbah dengan pengujian serum darah, kelompok peternakan dibagi menjadi dalam kelompok pengolahan limbah buruk dan kelompok pengolahan limbah baik. Pengelompokan sampel yang diuji 
pada pengolahan limbah berdasarkan beberapa penilaian meliputi penilaian saluran penampungan limbah, frekuensi pembersihan limbah yang ada dalam kandang dan penanganan pemanfatan limbah.

\section{Metode Pengujian}

Metode pengujian menggunakan uji enzyme linked immunosorbent assay (ELISA) antibodi sebagai uji screening awal. Dalam pengujian ini apabila didapatkan hasil positif, akan dilakukan pengujian lanjutan dengan uji ELISA antigen. Preparasi dan distribusi sampel meliputi beberapa persiapan yaitu penyiapan alat dan bahan untuk pengujian. Kit BVD antibodi diinkubasi pada suhu $18-26{ }^{\circ} \mathrm{C}$ selama 1 jam. Setelah itu plate uji disiapkan, kemudian dilakukan pengisian $100 \mu \mathrm{L}$ sample diluents ke dalam tiap sumur. Empat sumur pada kolom pertama microplate dikosongkan dari serum untuk dijadikan sumur kontrol positif dan negatif. Sebanyak $25 \mu \mathrm{L}$ kontrol negatif kemudian ditambahkan ke dalam sumur A1 dan B1. Selanjutnya sebanyak $25 \mu \mathrm{L}$ kontrol positif ditambahkan ke dalam sumur C1 dan D1, sedangkan serum sampel dimasukkan ke dalam sumur E1 sampai seterusnya sebanyak $25 \mu \mathrm{L}$ sesuai pola yang telah dibuat. Setelah itu dilakukan pengocokkan dan diinkubasi selama 90 menit pada suhu $18-26^{\circ} \mathrm{C}$. Pencucian menggunakan larutan pencuci (washing solution) sebanyak $300 \mu \mathrm{L}$ dan dilakukan aspirasi sebanyak lima kali sampai menyentuh dinding sumur. Sebanyak $100 \mu \mathrm{L}$ reagent konjugat ditambahkan ke dalam tiap sumur dan diinkubasi selama 30 menit pada suhu $18-26^{\circ} \mathrm{C}$, lalu dilakukan kembali langkah dan prosedur pencucian.

Sebanyak $100 \mu \mathrm{L}$ tetra methyl benzidine (TMB) substrat ditambahkan ke dalam tiap sumur, kemudian microplate ditutup dengan alumunium foil dan selama 10 menit diinkubasi pada suhu ruangan 18$26{ }^{\circ} \mathrm{C}$ di ruang gelap. Setelah itu, dilakukan penambahan $100 \mu \mathrm{L}$ stop solution untuk menghentikan reaksi dan dilakukan pembacaan dengan menggunakan ELISA reader pada panjang gelombang 450 $\mathrm{nm}$.

\section{Interpretasi Hasil ELISA AntibodiPrognosa}

Sampel dengan nilai sample value related to positive value (S/P) sebesar 0,3 atau lebih menunjukkan adanya antibodi terhadap BVD dan hasil uji berarti positif. Perhitungan (S/P) dapat dihitung dengan rumus sebagai berikut:

$(\mathrm{S} / \mathrm{P})=$ Nilai sampel yang diuji optical density $(\mathrm{OD})$ - nilai rataan kontrol negatif

Nilai rataan kontrol positif - nilai rataan kontrol negatif
Untuk sampel serum, plasma dan individual milk nilai (S/P) memiliki beberapa interpretasi sebagai berikut :

$$
\begin{array}{ll}
<0,20 & =\text { negatif } \\
\geq 0,20-0,30 & =\text { suspect } / \text { terindikasi } \\
>0,30 & =\text { positif }
\end{array}
$$

\section{Interpretasi Hasil ELISA Antigen}

Sampel dengan nilai koreksi dari nilai rata rata optical density (OD) kontrol positif dengan nilai rata rata optical density (OD) kontrol negatif atau (S-N) sebesar 0,3 atau lebih menunjukkan adanya antigen terhadap BVD dengan hasil uji positif. Perhitungan (S-N) dapat dihitung dengan rumus sebagai berikut:

$$
\begin{aligned}
& \text { Rumus S-N = Sampel }(P C x)-(N C x) \\
& P C x=\text { nilai rata rata optical density }(O D) \text { kontrol positif } \\
& N C x=\text { nilai rata rata optical density }(O D) \text { kontrol negatif }
\end{aligned}
$$

Untuk sampel serum, plasma dan individual milk nilai (S-N) memiliki interpretasi sebagai berikut :

$$
\begin{aligned}
& <0,30=\text { negatif } \\
& >0,30=\text { positif }
\end{aligned}
$$

\section{Kuesioner}

Kuesioner terkait faktor risiko penyebaran di kandang instalasi karantina hewan dengan hasil deteksi serologis penyakit BVD dilakukan pada perusahaan-perusahaan swasta yang memiliki instalasi karantina hewan. Pertanyaan kuisioner meliputi hal-hal program biosekuriti, pengelolaan limbah ternak, sistem pelaporan adanya kasus, penanganan pada hewan diare, sumber air yang diminum, penanggung jawab peternakan, dan kerapatan hewan per kandang di kandang isolasi Instalasi Karantina Hewan (IKH).

Analisis kuesioner yang dilakukan dalam pembahasan biosekuriti berdasarkan penilaian pada pengawasan isolasi hewan yang baru datang, pengawasan terhadap lalu lintas manusia maupun peralatan dan kebersihan kandang di instalasi karantina hewan. Kelompok faktor biosekurit peternakan yang diuji asosiasi dengan pengujian serum darah terbagi menjadi dua kategori yaitu kelompok biosekuriti buruk dan kelompok biosekuriti yang baik.

Analisis kuesioner yang dilakukan dalam pembahasan pengolahan limbah meliputi penilaian saluran penampungan limbah, frekuensi pembersihan limbah yang ada dalam kandang dan penanganan pemanfatan limbah. Kelompok faktor pengelolaan 
limbah sapi di peternakan yang akan diuji asosiasi dengan pengujian serum darah terbagi menjadi dua kategori yaitu kelompok pengelolaan limbah buruk dan kelompok pengolahan limbah yang baik.

\section{Analisis Data}

Data-data yang diperoleh dalam penelitian ini dianalisa secara deskriptif. Kuesioner dianalisis dengan analisis pengukuran asosiasi menggunakan odds ratio (OR), terkait faktor risiko penyebaran di kandang instalasi karantina hewan dengan hasil deteksi serologis penyakit BVD. Odds ratio merupakan suatu ukuran dalam statistik yang sering digunakan untuk mengetahui seberapa besar kontribusi faktor faktor terhadap frekuensi kejadian penyakit (Mc Gowan et al., 2008).

\section{HASIL}

Pengujian Serum Darah Sapi dengan ELISA Antibodi dan ELISA Antigen

Berdasarkan uji serologis dengan ELISA, semua instalasi karantina hewan di dalam peternakan feedlot menunjukkan hasil positif. Hasil pengujian serologis terhadap antibodi BVD didapat total ratarata persentase positif mencapai $63 \%$ sedangkan total rata-rata negatif $37 \%$. Daerah instalasi peternakan sapi yang mempunyai persentase positif tertinggi adalah daerah Tangerang dengan nilai $75 \%$. Sedangkan untuk daerah instalasi peternakan yang mempunyai persentase positif paling rendah adalah daerah Subang. Hasil persentase nilai positif antibodi BVD pada sapi potong impor yang diuji menggunakan metode ELISA disajikan pada Tabel 1.

Tabel 2 menunjukkan hasil dari 63 sampel serum darah sapi yang positif itu serum tersebut setelah dilakukan uji deteksi antigen menunjukkan hasil negatif. Dengan perincian kasus positif antibodi paling tinggi di daerah Tangerang dengan 15 sampel serum dan yang terendah pada daerah Subang dengan 10 sampel serum. Uji ELISA antigen dapat digunakan untuk mengetahui (screening) awal dalam mencari hewan yang mengalami infeksi persisten sebagai hewan penular utama dalam penyebaran penyakit BVD dalam kandang peternakan (Burgess, 1995). Uji ini merupakan terobosan terbaru dalam mendeteksi awal keberadaan dari hewan infeksi persisten yang terbukti akurat sebelum dilakukan uji polymerase chain reaction (PCR), selain itu akan lebih efisien waktu screening awal karena uji ini cepat dan akurat (Lanyon, 2014).

Tabel 3 menunjukkan kelompok biosekuriti yang buruk memiliki nilai hasil positif ELISA antibodi sebesar 49 ekor (72,05\%) sedangkan dari kelompok biosekuriti yang baik mempunyai nilai yang lebih kecil yaitu 14 ekor (43,75\%). Jumlah Instalasi karantina hewan yang memiliki program biosekuriti buruk mencapai 68 feedlot sedangkan yang sudah melalukan praktek biosekuriti yang baik hanya 32 feedlot. Hal ini berakibat masih tingginya prevalensi antibodi BVD dalam penelitian yang mencapai angka $63 \%$.

Hasil yang terlihat dalam Tabel 4, terlihat bahwa program biosekuriti yang buruk akan berpeluang 3,316 kali lebih besar menimbulkan hasil ELISA antibodi positif bila dibandingkan dengan peternakan yang memiliki program biosekuriti yang baik $(\mathrm{OR}=3,316 ; \mathrm{Cl}=1,380-7,967)$. Uji statistik proporsi terlihat berbeda nyata dan signifikan (nilai $p$ hitung $=0,006$ ) lebih kecil dari nilai $p$ a uji $=0,05$. Hasil ini menunjukkan ada asosiasi antara faktor program biosekuriti yang ada pada peternakan dengan kejadian penyakit BVD.

Tabel 5 menunjukkan kelompok pengelolaan limbah yang buruk memiliki nilai hasil positif ELISA antibodi sebesar 49 ekor (70,00\%) sedangkan dari kelompok pengelolaan limbah yang baik mempunyai nilai yang lebih kecil yaitu 14 ekor (46,67\%).

Tabel 1 Hasil pengujian serologis BVD dengan ELISA antibodi

\begin{tabular}{|c|c|c|c|c|c|}
\hline Daerah peternakan & Jumlah sampel & Positif & Negatif & $\begin{array}{c}\text { Persentase } \\
\text { positif (\%) }\end{array}$ & Persentase negatif (\%) \\
\hline Cianjur & 20 & 13 & 7 & 65 & 35 \\
\hline Bogor & 20 & 14 & 6 & 70 & 30 \\
\hline Tangerang & 20 & 15 & 5 & 75 & 25 \\
\hline Bandung & 20 & 11 & 9 & 55 & 45 \\
\hline Subang & 20 & 10 & 10 & 50 & 50 \\
\hline Total & 100 & 63 & 37 & 63 & 37 \\
\hline
\end{tabular}


Tabel 2 Hasil pengujian serologis BVD dengan ELISA antigen

\begin{tabular}{lccccc}
\hline $\begin{array}{l}\text { Daerah } \\
\text { peternakan }\end{array}$ & Jumlah sampel & Hasil ELISA Ab + & Persentase (\%) & Hasil ELISA Ag & Persentase (\%) \\
\hline Cianjur & 20 & 13 & 65 & 0 & 0 \\
Bogor & 20 & 14 & 70 & 0 & 0 \\
Tangerang & 20 & 15 & 75 & 0 & 0 \\
Bandung & 20 & 11 & 55 & 0 & 0 \\
Subang & 20 & 10 & 50 & 0 & 0 \\
\hline Total & 100 & 63 & 63 & 0 & 0 \\
\hline
\end{tabular}

Tabel 3 Kelompok faktor program biosekuriti dengan hasil ELISA antibodi positif pada sapi potong yang diimpor melalui Pelabuhan Tanjung Priok

\begin{tabular}{lccc}
\hline \multirow{2}{*}{ Biosekuriti } & \multicolumn{2}{c}{ Hasil ELISA antibody } & \multirow{2}{*}{ Jumlah } \\
\cline { 2 - 3 } & \multicolumn{1}{c}{ Positif } & Negatif & 68 \\
Buruk & $49(72,05 \%)$ & $19(27,95 \%)$ & 32 \\
Baik & $14(43,75 \%)$ & $18(56,25 \%)$ & 100 \\
\hline Jumlah & $63(63,00 \%)$ & $37(37,00 \%)$ & \\
\hline
\end{tabular}

Tabel 4 Nilai OR dari faktor program biosekuriti dengan hasil ELISA antibodi positif pada sapi potong yang diimpor melalui Pelabuhan Tanjung Priok

\begin{tabular}{ccccccc}
\hline No. & Biosekuriti & Positif & Negatif & Nilai $p$ & OR & $\mathrm{Cl} 95 \%$ \\
\hline 1 & Buruk & 49 & 19 & 0,006 & 3,316 & $1,380-7,967$ \\
2 & Baik & 14 & 18 & & & \\
\hline
\end{tabular}

$\mathrm{OR}=$ Odds ratio $; \mathrm{Cl} 95 \%$ = Confidential interval $95 \%$

Tabel 6 menunjukkan bahwa pengelolaan limbah yang buruk akan berpeluang 2,667 kali lebih besar menimbulkan hasil ELISA antibodi positif bila dibandingkan dengan peternakan yang memiliki pengelolaan limbah yang baik ( $\mathrm{OR}=2,667 ; \mathrm{Cl}=1,105-6,434)$. Uji statistik proporsi terlihat berbeda nyata dan signifikan (nilai $p$ hitung $=0,027$ ) lebih kecil dari nilai $p$ $a$ uji $=0,05$. Hasil ini menunjukkan ada asosiasi antara faktor program pengolahan limbah yang ada pada peternakan dengan kejadian penyakit BVD.

\section{PEMBAHASAN}

Hasil uji serologi antibodi yang didapat dari penelitian positif namun dalam uji serologi antigen negatif disebabkan beberapa hal. Antibodi yang terdeteksi terhadap virus BVD pada sapi ternak sapi potong di daerah peternakan dapat terjadi karena adanya infeksi alami pada waktu masa pemeliharan/penggemukkan di kandang (Fulton, 2006). Penyebaran penyakit terjadi secara langsung melalui kontak dengan hewan yang terinfeksi terutama yang mengalami infeksi persisten, sedangkan seca- ra tidak langsung melalui makanan yang tercemar urin, feses, sekresi oronasal atau dari cairan fetus yang mengalami abortus (Muhammad et al., 2004). Penularan dapat dibawa antar peternakan oleh petugas yang secara langsung kontak dengan sapi yang terinfeksi. Infeksi terjadi sangat cepat antara sapi yang peka melalui kontak langsung, tetapi tanda klinis yang terlihat tidak jelas yang disertai dengan masa inkubasi penyakit yang tidak teratur (Kahrs, 2005). Penyebab lain karena adanya transient infection yakni kejadian BVD yang menyerang sementara hanya dalam beberapa minggu pada individu sapi, setelah masa tersebut sapi akan terlihat normal kembali (Middleton, 2006). Fulton (2006) menjelaskan vaksinasi juga dapat menyebabkan adanya hasil serologi antibodi positif akan tetapi dari health certificate negara asal tidak ditemukan keterangan ada atau tidaknya vaksinasi yang dilakukan oleh negara Australia, untuk itu uji screening perlu dilakukan di negara Indonesia.

Tingginya titer antibodi pada sampel sapi potong impor asal Australia yang diperiksa ini berbanding lurus dengan tingginya tingkat prevalensi di negara Australia. Tingkat prevalensi antibodi pada 
Tabel 5 Kelompok faktor pengolahan limbah dengan hasil ELISA antibodi positif pada sapi potong yang diimpor melalui Pelabuhan Tanjung Priok

\begin{tabular}{llll}
\hline \multirow{2}{*}{ Pengolahan Limbah } & \multicolumn{2}{c}{ Hasil ELISA antibody } & \multirow{2}{*}{ Jumlah } \\
\cline { 2 - 3 } & \multicolumn{1}{c}{ Positif } & Negatif & \\
\hline Buruk & $49(70,00 \%)$ & $21(30,00 \%)$ & 70 \\
Baik & $14(46,67 \%)$ & $16(53,37 \%)$ & 30 \\
\hline Jumlah & $63(63,00 \%)$ & $37(37,00 \%)$ & 100 \\
\hline
\end{tabular}

ternak di Australia adalah sekitar 60\% sementara lebih dari $80 \%$ ternak telah terinfeksi penyakit BVD (Littlejohns, 1990). Pada tahun 2006 dilaporkan terjadi kasus BVD sebesar 1190 di Indonesia (OIE, 2006). Sudarisman (2011) menjelaskan bahwa dalam uji serologis ELISA terhadap serum serum sapi di berbagai daerah di Indonesia diketahui sebesar $37 \%$ sapi memiliki antibodi terhadap BVD. Prevalensi titer antibodi terhadap bovine pestivirus (71\%-88\%) dilaporkan lebih dari 20 tahun di Northern Australia dengan tingkat kejadian 40\%-92\% (Bedekovic et al., 2012).

Hubungan hasil uji serologis meningkat pada kelompok ternak dengan biosekuriti yang buruk akan terjadi bila faktor kurangnya pengawasan isolasi hewan yang baru datang, kurangnya pengawasan terhadap lalu lintas manusia maupun peralatan dan kurangnya kebersihan kandang. Program biosekuriti dalam peternakan memegang peranan penting dalam penyebaran penyakit BVD hal ini dikarenakan saat ini tidak ada perawatan efektif yang tersedia untuk menyembuhkan BVD, perawatan alternatif hanya antibiotik untuk mengobati infeksi sekunder yang ditimbulkan misalnya pneumonia (Ellis, 1998). Program biosekuriti yang banyak dilanggar meliputi kurangnya pengawasan lalu-lintas hewan yang keluar masuk ke dalam peternakan dan masih rendahnya kesadaran petugas kandang terhadap pentingnya sanitasi. Beberapa pencegahan yang dapat dilakukan meliputi, isolasi hewan yang memiliki gejala BVD dan setiap hewan yang memiliki kontak langsung dengan hewan sakit. Sanitasi kandang dan lingkungan sekitar kandang adalah penting untuk membantu mencegah penyebaran virus. Melakukan pembersihan rutin dengan desinfektan terutama peralatan kandang akan dapat secara efektif membunuh virus BVD dan untuk membantu mencegah penyebaran virus (Brennan et al., 2008). Langkah-langkah ini akan dapat membantu untuk memastikan kawanan ternak dapat terhindar dari infeksi. Beberapa pencegahan yang dapat dilakukan meliputi, isolasi hewan yang memiliki gejala BVD dan setiap hewan yang memiliki kontak langsung dengan hewan sakit (Ajid, 2004). Disarankan bahwa perawatan untuk sapi bunting dipisahkan dari hewan yang yang lain dan peralatan yang digunakan juga dipisahkan (Cornish, 2005).

Faktor yang berpengaruh terhadap kejadian penyakit BVD lainnya adalah pengelolaan limbah di dalam peternakan. Kotoran ternak merupakan media yang potensial untuk menularkan penyakit. Banyak penyakit yang bisa ditularkan akibat kontaminasi feses antara lain salmonellosis, paratuberculosis, bovine viral diarrhea (BVD) dan lain-lain. Risiko penularan penyakit ke manusia akan semakin tinggi jika kotoran ternak ini tidak dikelola dengan baik dan benar. Penyebaran kotoran (feses) sebagai salah satu media penularan penyakit dapat terjadi akibat adanya petugas/pengunjung dalam satu hari melakukan pengawasan lebih dari setengah area peternakan dan tidak melakukan disinfeksi terhadap peralatan dan kendaraan yang digunakan. Risiko juga dapat terjadi pada pengunjung dengan frekuensi kunjungan ke peternakan lebih dari satu dalam sehari, selain itu penyebaran agen patogen pada area peternakan dapat terjadi melalui fomite (Brennan et al., 2008).

Kesimpulan penelitian berdasarkan uji screening awal mengggunakan ELISA antibodi BVD terhadap 100 sampel serum darah sapi, ditemukan 63 positif terhadap antibodi anti BVD. Hal ini mengindikasikan adanya infeksi BVD yang perlu diwaspadai oleh feedlot di Indonesia karena sifat penyebaran BVD ini sangat mudah menular antara hewan satu dengan yang lain di dalam populasi ternak. Hasil analisa kuesioner menunjukkan ada asosiasi antara kedua faktor yang ada pada peternakan dengan kejadian penyakit BVD. Program biosekuriti pada peternakan dengan nilai $(\mathrm{OR}=3,316 ; \mathrm{Cl}=1,380-7,967)$. Selain itu pengelolaan limbah kandang dalam peternakan dengan nilai $(\mathrm{OR}=2,667 ; \mathrm{Cl}=1,105-6,434)$.

\section{UCAPAN TERIMA KASIH}

Ucapan terima kasih disampaikan kepada Badan Karantina Pertanian dan Balai Besar Karantina Pertanian Tanjung Priok yang telah memberi dana 
bantuan penelitian dan kepada seluruh staf Laboratorium Balai Besar Uji Standar Pertanian yang telah membantu dalam pelaksanaan penelitian.

"Penulis menyatakan tidak ada konflik kepentingan dengan pihak-pihak terkait dalam penelitian ini".

\section{DAFTAR PUSTAKA}

Ajid R. 2004. Strategi alternatif pengendalian penyakit reproduksi menular untuk meningkatkan efisiensi reproduksi sapi potong. Wartazoa 14: 8-14.

Baker JC. 1995. The clinical manifestations of bovine viral diarrhea infection. Veterinary Clinic North Food Animal Practice 11: 425-445.

Bedekovic T, Jemersici L, Lojkici I, Lemoi N, Kerosi T, Balatinaci J, Brnici D, Ivkovici TC, Madic J. 2012. Bovine viral diarrhoea: Ag ELISA and reverse transcription polymerase chain reaction as diagnostic tools in pooled serum samples from persistently infected cattle short communication. Journal Veterinarski Arhive 82: 295-301.

Brennan ML, Kemp R, Christley RM. 2008. Direct and indirect contacts between cattle farms in north-west England. Journal Veterinary Medical 84: 24-260.

Burgess GW. 1995. Teknologi ELISA dalam Diagnosis dan Penelitian. Artama, WT, penerjemah. Yogyakarta (ID): UGM Pr. Terjemahan dari: ELISATechnology in Diagnosis and Research.

Cornish T. 2005. Comparisson of ear notch immunohistochemistry ear notch antigen-capture ELISA and buffy coat virus isolation for detection of calves persistenly infected with bovine viral diarrhea virus. Journal Veterinary Diagnostic Investigation. 17: 110-117.
Ellis JA. 1998. Lesions and distribution of viral antigen following an experimental infection of young seronegative calves with virulent bovine virus diarrhea virus type II. Can Journal Veterinary Res 62: 161-169.

Fulton R. 2006. Bovine viral diarrhea virus persistent infections in beef breeding herds. Journal Medical Virology 23: 143-149.

Kahrs RF. 2005. Viral Disease of Cattle Second Edition. lowa (US): lowa State University Pr.

Lanyon SR, Hill FI, Reschels MP, Brownlie J. 2014. Bovine viral diarrhea pathogenesis and diagnosis. Journal Veterinary 199: 201-209.

Littlejohns IR. 1990. Incidence, epidemiology and control of bovine pestivirus infections an disease in New Zealand and Australia. Auckland (NZ): Blackwell Pr.

McGowan M, Kirkland P, Howard R, Morton J, Younis P, Bergman, E, Cusack, P. 2008. Guidelines for the investigation and control of BVDV (Bovine Viral Diarrhoea Virus or Bovine Pestivirus) in beef and dairy herds and feedlots.[Internet]. Download: 16 Agustus 2014.

Middleton D. 2006. Vaccination of the cow in Western Canada. Journal Medical Virology 12: 25-34.

Muhammad D, Rauf F, Yudiastyas DW. 2004. Situasi kasus bovine viral diare pada sapi di Sulawesi Selatan tahun 2004. Bulletin Informasi Kesehatan Hewan dan Kesehatan Masyarakat Veteriner 2: 12-16.

[OIE] Office International des Epizooties. 2006. Indonesia report for 2005. Paris (FR): OIE.

Sudarisman. 2011. Bovine viral diarrhea pada sapi di Indonesia dan permasalahannya. Wartazoa 21: 18-24. 